\title{
Pendampingan Metode Pembelajaran Storytelling dalam Program Konservasi Penyu Laut di SMA Negeri 1 Samatiga Aceh Barat
}

\author{
Rina Syafitri' ${ }^{1}$, Mohamad Gazali², Faizatul Husna ${ }^{3}$ \\ 1Jurusan Agribisnis, Universitas Teuku Umar \\ Email: rinasyafitri@utu.ac.id \\ 2Jurusan Ilmu Kelautan, Universitas Teuku Umar \\ Email: mohamadgazali@utu.ac.id \\ 3Jurusan Pendidikan Bahasa Inggris, Sekolah Tinggi Agama Islam Teungku Dirundeng \\ Email: faizatulhusna88@gmail.com
}

\begin{abstract}
The coastal community of West Aceh have marine topography that infront of Hindia ocean directly with various marine biota that distributed at coast and seawater. One of the marine biota that critically extinct is sea turtle. It is necessary to effort sea turtle's conservation that aimed to defends that animal populations in nature. Therefore, we have conducted the empowering community programme with engagement used storytelling learning method to students of Public Senior High School 1 Samatiga West Aceh. The aimed to enhance the awareness in preserving sea turtle at the West Aceh coast. The conducting method through individual and classical approach. The classical approach was undertaken in giving the theory about sea turtle via story method and individual approach was conducted in exercise and filled puzzle. There are method that used was learning method storytelling. The result including delivering material regarding introduction sea turtle by using learning method based on retteling story. According the program was identified the understanding level of student regarding sea turtle via learning method of storytelling as much as $85 \%$. It is describe from output of activity such as retelling story activity and arrangement of puzzle. The students gave positive response and enthusiasm in which the information that provided to give insight about sea turtle in their environment. Otherwise, we conducting wacthing the video with present about the sea turtle's life in nature and enter moral message to preserve the sea turtle.
\end{abstract}

Keywords: Sea turtle; Storytelling; Conservation; Learning Method; Engagement

\begin{abstract}
Abstrak
Pesisir Aceh Barat memiliki topografi laut yang berhadapan langsung dengan Samudera Hindia dengan beragam biota-biota laut yang tersebar di pesisir dan laut. Salah satu biota laut yang terancam punah adalah penyu laut di alam. Hal ini perlu dilakukan upaya konservasi penyu yang bertujuan mempertahankan populasi hewan tersebut. Oleh karena itu, kami melaksanakan program pengabdian kepada masyarakat dengan melakukan pendampingan menggunakan metode pembelajaran Storytelling kepada siswa/siswi SMAN 1 Samatiga Aceh Barat. Tujuan pelaksanaan pengabdian kepada masyarakat adalah untuk menumbuhkan kesadaran dalam melestarikan penyu laut di pesisir Aceh Barat. Metode pelaksanaan melalui pendekatan individual dan klasikal. Pendekatan klasikal dilakukan pada saat pemberian teori tentang penyu melalui metode bercerita dan pendekatan individual dilakukan pada saat latihan dan pengisian puzzle. Adapun metode yang digunakan adalah metode pembelajaran storytelling. Hasil pelaksanaan pengabdian meliputi penyampaian materi tentang pengenalan hewan penyu dengan metode pembelajaran berbasis retelling story. Berdasarkan hasil kegiatan, dapat diidentifikasi bahwa tingkat pemahaman siswa mengenai penyu melalui metode storytelling adalah sebesar $85 \%$. Hal ini terlihat dari output kegiatan berupa kegiatan retelling
\end{abstract}


story (bercerita kembali) dan penyusunan puzzle. Siswa juga memberi tanggapan positif dan antusias dimana informasi yang disediakan memberikan wawasan mengenai penyu yang ada disekitar mereka. Selain itu, kami melakukan pemutaran video animasi penyu dengan menyajikan konten-konten tentang pola kehidupan penyu di alam dan menyisipkan pesanpesan moral akan pentingnya melestarikan penyu laut.

Kata Kunci: Penyu; Storytelling; Konservasi; Metode Pembelajaran; Pendampingan

\section{PENDAHULUAN}

Aceh Barat Terletak di bagian ujung pulau sumatera di pesisir barat, luas wilayah Kabupaten Aceh Barat mencapai 2,927,95 $\mathrm{Km}^{2}$ dengan panjang garis pantai diperhitungkan $50.55 \mathrm{~km}$ dengan laut 12 mil $233 \mathrm{~km} 2$ daratan (Kementerian Kelautan dan Perikanan, 2015).

Tiga desa pesisir pantai yang yang telah teridentifikasi sebagai areal peneluran penyu, yaitu desa Lhok Bubon, Suak Seumaseh, dan Meureubo. Penyu laut merupakan reptilia laut yang hidup di laut serta mampu bermigrasi dalam jarak yang jauh di Sepanjang kawasan Samudera Hindia, Samudra Pasifik dan Asia Tenggara. Keberadaannya telah lama terancam, baik oleh faktor alam maupun faktor kegiatan manusia yang membahayakan populasinya secara langsung maupun tidak langsung.

Penyu merupakan kura-kura laut yang masuk kelompok hewan vertebrata kelas reptilia ordo Testudinata. Hewan ini memiliki kulit yang bersisik, berdarah dingin, bernapas dengan paru-paru, dan berkembang biak dengan bertelur. Daging penyu memiliki kandungan protein yang tinggi sedangkan karapaks dapat dimanfaatkan menjadi perhiasan manusia.
Siripnya sempurna sehingga mampu bermigrasi dalam jarak yang jauh mengarungi Samudera Hindia, Samudera Pasifik, dan Samudera Atlantik (Hughes, 1977).

Penyu dalam satu kali bertelur menghasilkan ratusan butir, namun yang dapat bertahan hidup hanya beberapa butir sehingga menurut IUCN (International Union Conservation of Nature and Natural Reserve) tahun 1963 menyatakan bahwa kondisi tersebut yang menyebabkan jumlah populasi menurun. Penyu dilindungi sejak tahun 1980 berdasarkan keputusan Menteri Pertanian No. 716/KptsUm/10/1980 (Salim, 1992).

Seluruh jenis penyu saat ini dikategorikan kedalam "endangered species" oleh International Union for Conservation of Nature and Natural Resources (IUCN), yang berarti terancam punah dan masuk kedalam Red Data Book, (Tomascik et al. 1997). Conventation on International Trade in Endangered Species of Wild Fauna and Flora (CITES) menyatakan bahwa seluruh penyu 15 termasuk Appendix 1 Artinya, seluruh penyu tidak boleh diperjualbelikan, karena jumlahnya di alam sedikit dan dikhawatirkan terancam punah (Soehartono dan Mardiastuti, 2003).

Di Indonesia terdapat 6 dari 7 jenis penyu yang ada di dunia, yaitu 
penyu belimbing (Dermochelys coriacea), penyu hijau (Chelonia mydas), penyu sisik (Eremochelys imbricate), penyu lekang (Lepidochelys olivacea), penyu tempayan (Caretta caretta), dan penyu pipih (Natator depresus) (Salim, 1992). Jumlah ini sebenarnya masih menjadi perdebatan karena Nuitja (1992) menyebutkan hanya lima jenis yang ditemukan, dimana Caretta caretta dinyatakan tidak ada. Namun demikian, beberapa peneliti mengungkapkan bahwa Caretta caretta memiliki daerah jelajah yang meliputi Indonesia.

Kerusakan habitat pantai dan ruaya pakan, kematian akibat interaksi dengan aktivitas perikanan, pengelolaan teknikteknik konservasi yang tak memadai, perubahan iklim, penyakit serta pengambilan penyu dan telurnya yang tidak terkendali merupakan faktor-faktor penyebab penurunan populasi penyu.

Upaya sosialisasi program konservasi penyu laut sudah dilakukan oleh pemerintah daerah dan Lembaga Swadaya Masyarakat (LSM). Namun, pelaksanaan kegiatan tersebut masih kurang efektif dalam pencapaian outcomes bagi masyarakat pesisir. Oleh karena itu, kami mencoba melakukan modifikasi sosialisasi dengan metode pembelajaran yang efektif dan efisien kepada generasi muda melalui sekolah-sekolah meliputi sekolah menengah atas. Metode pembelajaran (learning method) yang digunakan adalah metode pembelajaran storytelling.
Storytelling sangat menarik bagi pembelajar karena berisi pengalaman yang indah, lucu dan menarik. Banyak orang memakai story untuk meninabobokan anak, memberi petuah dari orang tua dari orang tua kepada orang muda dan menceritakan hal-hal tersebut tidak mahal. Melalui cerita banyak hal yang dapat disampaikan dan dipahami oleh pendengar, karena penyampaiannya menarik, bahasa yang digunakan juga lebih sederhana. Situasi memberikan kesan yang tersendiri bagi pendengar, karena mereka merasa rileks. Melihat situasi ini, maka metode pembelajaran ini efektif dan efisien bagi generasi muda untuk memberikan informasi terkait upaya konservasi penyu laut.

Banyak sekolah yang didirikan pada di dekat habitat peneluran penyu. Sementara itu, kegiatan eksploitasi penyu beserta turunannya masih memprihatinkan. Disisi lain, anak-anak generasi muda belum dibekali pengetahuan dan informasi yang memadai terkait upaya konservasi penyu yang ada di wilayah Kabupaten Aceh Barat. Hal ini menjadi iniasitif bagi kami untuk melakukan program konservasi penyu laut dengan metode pembelajaran (learning method) yang tepat untuk diimplementasikan kepada siswa/siswi yang ada di sekolahsekolah. Tujuan kegiatan pengabdian kepada masyarakat ini adalah untuk menumbuhkan kesadaran dalam melestarikan penyu laut di pesisir Aceh Barat dan memberikan informasi kepada 
siswa SMAN 1 Samatiga tentang deskripsi penyu laut.

\section{METODE PELAKSANAAN}

Profil masyarakat sasaran yaitu siswa/siswi Sekolah Menengah Atas (SMA) Negeri 1 Samatiga. Pengusul memilih siswa-siswa perwakilan kelas 1, 2 dan 3 yang dijadikan sebagai mitra Pengabdian Kepada Masyarakat.

Selanjutnya, untuk memecahkan masalah yang sudah diidentifikasi dan dirumuskan tersebut di atas, pengabdian dilakukan dengan pendekatan individual dan klasikal. Pendekatan klasikal dilakukan pada saat pemberian teori tentang penyu melalui metode bercerita dan pendekatan individual dilakukan pada saat latihan dan pengisian puzzle. Adapun metode yang digunakan adalah metode pembelajaran storytelling. Metode ini dipilih untuk menyampaikan konsep-konsep yang penting untuk dimengerti dan dikuasai oleh para siswa. Penggunaan metode ini dengan pertimbangan bahwa metode ceramah yang dikombinasikan dengan gambargambar, animasi dan display dapat memberikan materi yang relatif banyak secara padat, cepat dan mudah.

\section{HASIL DAN PEMBAHASAN}

Pelaksanaan

Pembelajaran

Storytelling

Pengabdian dilaksanakan di SMA Negeri 1 Samatiga dan melibatkan 50 peserta yang terdiri atas perwakilan siswa kelas 1, 2 dan 3.

Kegiatan berlangsung di aula utama sekolah mulai pukul 10.00 hingga 12.00 WIB dan dimulai pada bulan September 2018. Dalam penyampaian materi tentang pengenalan hewan penyu dengan metode pembelajaran berbasis retelling story akan diberikan sesuai dengan jadwal yang disusun oleh tim pengusul. Berdasarkan hasil kegiatan, dapat diidentifikasi bahwa tingkat pemahaman siswa mengenai penyu melalui metode storytelling adalah sebesar $85 \%$. Berikut disajikan Gambar 1 dan 2 saat pelaksanaan storytelling bersama perwakilan dari siswa SMA Negeri 1 Samatiga.

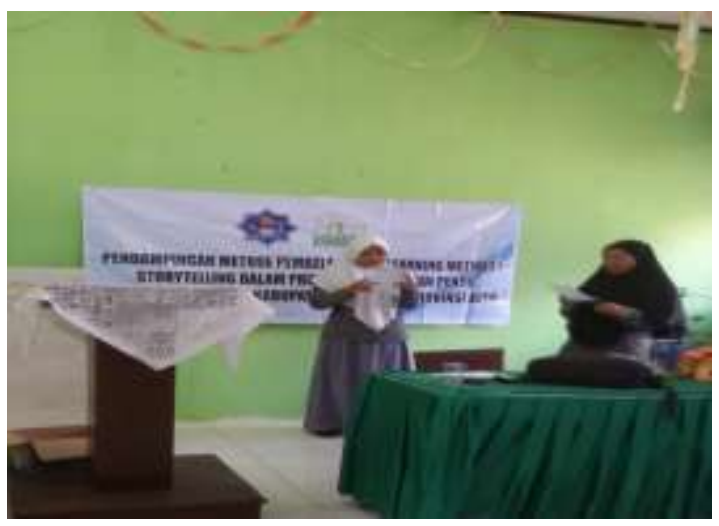




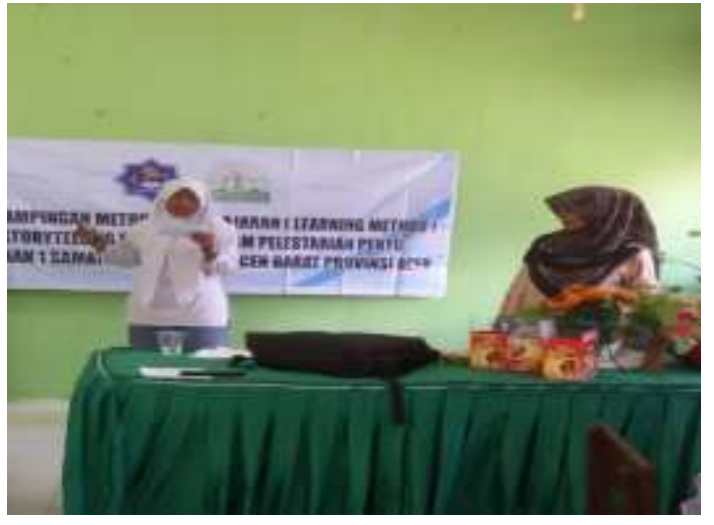

Gambar 1 dan 2. Pelaksanaan storytelling oleh perwakilan siswa

Output dari kegiatan yang dilakukan berupa kegiatan retelling story (bercerita kembali) oleh siswa serta penyusunan puzzle oleh siswa. Siswa juga memberi tanggapan positif dan antusias mengenai sosialisasi yang diberikan oleh tim pengusul, dimana informasi yang disediakan memberikan wawasan mengenai penyu yang ternyata masih ada disekitar mereka. Disamping itu, siswa juga terlihat mulai menyadari pentingnya konservasi penyu yang dilakukan oleh berbagai pihak.

\section{Pemutaran Video Animasi}

Dalam proses pemutaran video animasi penyu, kami menyajikan konten-konten tentang pola kehidupan penyu di alam dan menyisipkan pesan-pesan moral akan pentingnya menjaga penyu dari kepunahan akibat predator dan perburuan serta pencemaran laut. Hal ini mensugesti alam bawah sadar anak-anak dengan penghayatan yang mendalam sehingga dapat tersimpan dalam memori anak-anak.

Video animasi yang diberikan dalam sosialisasi tersebut juga menggambarkan proses perkembangbiakan di alam sampai penyu mengalami kedewasaan. Metode penyuluhan tersebut sangat efektif menarik minat siswa/siswi dalam mengenal dan merespon konservasi penyu yang ada di Wilayah Pesisir Samatiga (Aceh Barat).

Ketercapaian tujuan kegiatan ini secara umum sudah baik, namun keterbatasan waktu yang disediakan mengakibatkan tidak semua materi tentang sosialisasi bioekologi penyu dapat disampaikan secara detil. Disamping pengetahuan peserta didik mengenai bioekologi penyu masih sangat terbatas, sehingga pemberian materi awal memakan waktu yang lebih lama terlebih ketika menjelaskan istilah tertentu mengenai bioekologi penyu. Namun dilihat dari hasil latihan para peserta yaitu kualitas media pembelajaran yang telah dihasilkan, maka dapat disimpulkan bahwa tujuan kegiatan ini dapat tercapai.

Kegiatan pelatihan ini juga dapat dikatakan berjalan dengan lancar. Faktor pendukung berjalannya kegiatan pengabdian ini diantaranya antusisme para siswa mengenai bioekologi penyu. Antusisme dibuktikan dengan banyaknya pertanyaan yang 
muncul ketika pelaksanaan ceramah, tanya jawab dan pengerjaan tugas yaitu kegiatan retelling story dan penyusunan puzzle serta tidak adanya peserta yang membolos selama pelatihan.

\section{PENUTUP}

Program pengabdian ini dapat diselenggarakan dengan baik dan berjalan dengan lancar sesuai dengan rencana kegiatan yang telah disusun meskipun kebanyakan siswa belum terlalu familiar dengan materi yang berkaitan dengan bioekologi penyu. Kegiatan ini mendapat sambutan sangat baik terbukti dengan keaktifan siswa mengikuti kegiatan perlombaan retelling story dan menyusun puzzle penyu laut.

\section{DAFTAR PUSTAKA}

Hughes, G.R., 1977. Sea Turtles, “A Sample Guide to the Southern African SpecieswithNotes of Interest on their General Biology". Migration and Conversation Status. Natal Parks Boards.

Kementerian Kelautan dan Perikanan Republik Indonesia (KKP-RI). 2015. Surat edaran dari Menteri Perikanan dan Kelautan Nomor 526/MENKP/VIII/2015 Tentang Pelaksanaan Perlindungan Penyu, telur, Bagian Tubuh dan/atau Produk Turunannya. Jakarta.
Nuitja, I.N.S. 1992. Biologi dan Ekologi Pelestarian Penyu Laut. Bogor: IPB Press.

Salim, N., 1992. Studi Laju Pertumbuhan Juvenil Penyu Sisik Pada Pemberian Jenis Makanan dan Pergantian Air yang Berbeda. Karya Ilmiah. Jurusan Manajemen Sumberdaya Perairan. IPB : bogor.

Soehartono T. dan A. Mardiastuti. 2003. Pelaksanaan Konvensi CITES di Indonesia. Jakarta: Japan International Cooperation Agency (JICA).

Tomascik. 1997. The Ecology of the Indonesian Sea Part 2. Singapore: Peripilus Edition. 